\title{
Morphological and molecular diagnosis of Pseudoterranova decipiens (sensu stricto) (Anisakidae) in imported cod sold in Brazil
}

\author{
Diagnose morfológica e molecular de Pseudoterranova decipiens (sensu stricto) (Anisakidae) \\ em bacalhau importado vendido no Brasil \\ Cláudio Mafra ${ }^{1}$; Cynthia Mantovani ${ }^{1,2}$; Juliana Novo Borges ${ }^{3,4}$; Rafael Mazioli Barcelos ${ }^{1,2}$; Cláudia Portes Santos ${ }^{3 *}$ \\ ${ }^{1}$ Laboratório de Parasitologia e Epidemiologia Molecular, Departamento de Bioquímica e Biologia Molecular, \\ Universidade Federal de Viçosa - UFV, Viçosa, MG, Brasil \\ ${ }^{2}$ Programa de Pós-Graduação em Bioquímica Agrícola, Universidade Federal de Viçosa - UFV, Viçosa, MG, Brasil \\ ${ }^{3}$ Laboratório de Avaliação e Promoçáo da Saúde Ambiental, Instituto Oswaldo Cruz - Fiocruz, Rio de Janeiro, RJ, Brasil \\ ${ }^{4}$ Programa de Pós-Graduação em Biodiversidade e Saúde, Instituto Oswaldo Cruz - Fiocruz, Rio de Janeiro, RJ, Brasil
}

Received February 9, 2015

Accepted April 23, 2015

\begin{abstract}
An anisakid nematode larva found in cod sold in the state of Minas Gerais, Brazil was studied by light and scanning electron microscopy and by a molecular approach. Mitochondrial cytochrome c-oxidase subunit 2 (mtDNA cox-2), $28 \mathrm{~S}$ rRNA and ITS1, 5.8S and ITS2 regions were amplified using the polymerase chain reaction and sequenced to evaluate the phylogenetic relationships of the larva. The genetic profile confirmed that this larva belongs to the species Pseudoterranova decipiens (sensu stricto). This is the first molecular and ultrastructural study of Pseudoterranova decipiens (sensu stricto) in imported cod sold in Brazil. The health implications of these findings are discussed.
\end{abstract}

Keywords: Anisakiasis, codworm, food safety, public health.

\section{Resumo}

Uma larva de Nematoda anisakídeo encontrada em bacalhau comercializado no Estado de Minas Gerais, Brasil foi estudada por microscopias de luz e eletrônica de varredura e por uma abordagem molecular. As regióes da subunidade 2 da citocromo c-oxidase mitocondrial (mtDNA cox-2), 28S rRNA e ITS1, 5.8S e ITS2 foram amplificadas usando a reação em cadeia da polimerase e sequenciadas para avaliar as relaçóes filogenéticas da larva. O perfil genético confirmou que esta larva pertence à espécie Pseudoterranova decipiens (sensu stricto). Esse é o primeiro estudo molecular e ultraestrutural de Pseudoterranova decipiens (sensu stricto) de bacalhau importado vendido no Brasil. As implicações destes resultados para a saúde são discutidas.

Palavras-chave: Anisakíase, bacalhau, segurança alimentar, saúde pública.

\section{Introduction}

Fishes known as cod actually comprise five different species. The term 'cod' originally referred to fishes from the Atlantic and Pacific Oceans that are processed by salting and drying (OLIVEIRA et al., 2012). Among these species, Gadus morhua Linnaeus, 1758 and Gadus macrocephalus Tilesius, 1810 (Gadidae) are known as Atlantic and Pacific cod that occur, respectively, in the North Atlantic and Pacific Oceans. Brazil imports salted

*Corresponding author: Claúdia Portes Santos. Laboratório de Avaliação e Promoção da Saúde Ambiental, Instituto Oswaldo Cruz - Fiocruz, Av. Brasil, 4365, CEP 21040-900, Manguinhos, Rio de Janeiro, RJ, Brasil. e-mail: cpsantos@ioc.fiocruz.br cod mainly from Norway and Portugal, and according to Brazil's Ministry of Fisheries and Aquaculture, 45 million tons were sold in 2011 (BRASIL, 2013). These fish are known to host different helminth parasites, including anisakid nematodes (CHANDRA \& KHAN, 1988; HEMMINGSEN \& MACKENZIE, 2001; PERDIGUERO-ALONSO et al., 2008; CATALANO et al., 2014; MEHRDANA et al., 2014). In addition to G. morbua and G. macrocephalus, other species of salted fish are sold erroneously as cod in Brazil, namely saithe Pollachius virens (Linnaeus, 1758), ling Molva molva (Linnaeus, 1758) and tusk (zarbo) Brosme brosme (Ascanius, 1772) (LIMA \& SANT'ANA, 2011). Reports of the 
occurrence of anisakid nematodes in cod and other similar salted and dried fish sold in Brazil have begun to appear (PRADO \& CAPUANO, 2006).

Due to their zoonotic potential and possibility of inducing allergic reactions (RAMOS, 2011; SUZUKI et al., 2010; NIEUWENHUIZEN \& LOPATA, 2013), the occurrence of parasites in fish is considered a quality defect, according to Margeirsson et al. (2007), and as such, they are included in regulatory recommendations for the consumption of salted or dried salted fish in Brazil (BRASIL, 2007). With regard to the harmful effects of these parasites on human health, various authors have produced contradictory results/conclusions about the efficacy of salting to inactivate helminth larvae (RAMOS, 2011). Some authors claim that only live parasites can affect human health (ALONSO et al., 1997; RODRÍGUEZ et al., 2006; AUDICANA \& KENNEDY, 2008), while others have demonstrated that even inactivated parasites can cause allergic reactions (FERNÁNDEZ DE CORRES et al., 1996; DEL REY MORENO et al., 2006; VIDACEK et al., 2009).

Cases of human infection resulting from the ingestion of live anisakid larvae have been reported in various geographical regions (MERCADO et al., 2001; YU et al., 2001; CABRERA et al., 2003; NA et al., 2013; QIN et al., 2013; CHOI et al., 2014; RAMANAN et al., 2013). In Brazil, probable human cases are rare (AMATO et al., 2007; CRUZ et al., 2010), although these larvae do occur in different marine fishes in the region (MATTIUCCI et al., 2002; LUQUE et al., 2011; BORGES et al., 2012; FONTENELLE et al., 2013; KNOFF et al., 2013).

Members of the Anisakidae Skrjabin \& Karokhin, 1945 in cod include species of the genus Pseudoterranova Mozgovoi, 1950, whose larvae reportedly cause human anisakiasis and pseudoterranoviasis through the ingestion of inadequately cooked fish (MATTIUCCI \& NASCETTI, 2008; PERDIGUERO-ALONSO et al., 2008; TIMI et al., 2014). Although this genus has been known mainly in terms of the species complex Pseudoterranova decipiens (sensu lato), it actually includes the following species: Pseudoterranova decipiens Krabbe, 1878 (sensu stricto); P. krabbei Paggi, Mattiucci, Gibson, Berland, Nascetti, Cianchi \& Bullini, 2000; P. bulbosa Cobb, 1888; P. azarasi Yamaguti \& Arima, 1942; P. cattani George-Nascimento \& Urrutia, 2000; P. kogiae (Johnston \& Mawson, 1939); and P. ceticola (Deardorff \& Overstreet, 1981) (see MCCLELLAND, 2002; MATTIUCCI \& NASCETTI, 2008; ARIZONO et al., 2011; TIMI et al., 2014). These larvae are difficult to differentiate and identify to the level of species based solely on morphology because there are few or no diagnostic characters at this level; hence, the need for species assignation based on genetic analyses. A few recent studies have reported the presence of Pseudoterranova larvae in cod based on molecular identification (BUCHMANN \& KANIA, 2012; PUFALL et al., 2012). This study aims to identify the species of anisakid larvae occasionally found in salted cod sold as $G$. morhua in the municipality of Viçosa, southeastern Brazil.

\section{Materials and Methods}

A single nematode larva removed from three fleshs $(1 \mathrm{Kg})$ of salted cod sold in the municipality of Viçosa, state of Minas Gerais, Brazil (20 45’14” S, 42 $52^{\prime} 55^{\prime}$ W) was washed in distilled water, cut into three pieces and fixed in $70 \%$ ethanol.
The anterior and posterior regions were cleared in glycerine for examination by light microscopy. These fragments were then washed in 70\% alcohol, dehydrated in an ethanol series, critical point dried with $\mathrm{CO}_{2}$, coated with $20 \mathrm{~nm}$ of gold, and examined in a JEOL JSM-6390 scanning electron microscope.

The middle portion of the parasite was prepared for total genomic DNA extraction using the modified phenol/chloroform method developed by Billings et al. (1998). The primers used were 390 (5'-ATCCGTGTTTCAAGACGGG-3') and 391 (5'-AGCGGAGGAAAAGAAACTAA-3') for 28S rRNA gene (NADLER et al. 2005), NC5 (5'-GTAGGTGAACCTGCGGAAGGATCATT-3') and NC2 (5'- TTAGTTTCTTTTCCTCCGCT-3') for ITS1, 5.8S and ITS2 genes (UMEHARA et al., 2006), and 210 (5'-CACCAACTCTTAAAATTATC-3') and 211 (5'-TTTTCTAGTTATATAGATTGRTTTYAT-3') for mitochondrial cytochrome c-oxidase subunit 2 (cox-2) (NADLER \& HUDSPETH, 1998). PCR was carried out using cycling parameters, as previously described (NADLER \& HUDSPETH, 1998; FLOYD et al., 2002; NADLER et al., 2005; UMEHARA et al., 2006). The PCR products were visualized with SYBR green stain (Invitrogen, Eugene, OR, USA) before electrophoresis on 1.5\% agarose gel. Amplified PCR products were purified using a Wizard ${ }^{\circledast}$ SV Gel and PCR Clean-Up System (Promega, Madison, WI, USA).

DNA cycle-sequencing reactions were performed using BigDye v.3.1 chemistry (Applied Biosystems, Foster City, CA, USA), while the sequencing reactions were performed in an $\mathrm{ABI}$ Prism 3100 genetic analyzer. The sequences were edited using DNASTAR SeqMan (DNASTAR, Inc., Madison, WI, USA) and compared for similarities with sequences from GenBank, using BLAST 2.0 (ALTSCHUL et al., 1990). To examine the phylogenetic relationships, the nucleotide sequences were analyzed using the CLUSTAL W algorithm of the BioEdit Package (THOMPSON et al., 1994; HALL, 1999). The Maximum Likelihood (ML) phylogenetic tree (FELSENSTEIN, 1981) was inferred with MEGA 5.0 software (TAMURA et al., 2011), using the Kimura 2-parameter (K2P) model, and gamma distribution was selected by MEGA 5.0. The Maximum Likelihood tree was resampled by 5,000 bootstrap replicates to evaluate the reliability of the groups. The model of evolution for the Bayesian inference (BI) tree was GTR $+\gamma+\mathrm{I}$, and default priors were estimated using MrBayes 3.1.2 software (HUELSENBECK \& RONQUIST, 2001). After 2,000,000 generations for convergence, $25 \%$ of the trees were discarded as burn-in and the rest were used for topology and posterior probability reconstruction.

\section{Results and Discussion}

The initial examination using light microscopy revealed that the worm was a third-stage anisakid larva with a boring tooth situated between the ventrolateral lips, the excretory pore at the base of the ventrolateral lips, a long ventriculus but no ventricular appendix, an intestinal caecum and a tail with a mucron. The scanning electron microscopy observations revealed three poorly developed lips, i.e., a dorsal lip bearing a pair of double papillae 
and two ventrolateral lips (Figure 1a). The tail bore a terminal mucron (Figure 1b-d). Based on the morphology of the larva, it was identified as a species of Pseudoterranova Mozgovoi, 1951.

The subsequent molecular analysis enabled a direct comparison of the ITS1, 5.8S, ITS2 and 28S rDNA and the mitochondrial cytochrome c-oxidase subunit $2(\operatorname{cox}-2)$ sequences with those of Pseudoterranova decipiens Krabbe, 1878 (sensu stricto) in GenBank (GenBank accession numbers KF806033, KF806034 and KF806035). For cox-2 (accession number KF806035), the BLAST results indicated $98 \%$ identity with $100 \%$ query cover and a maximum score of 399 for $P$. decipiens, and $99 \%$ identity with $74 \%$ of query cover and a maximum score of 309 for $P$. azarasi. For the 28S gene (accession number KF806033) in relation to P. decipiens, there was a $100 \%$ identity, $99 \%$ query cover and a maximum score of 1382; no match was found for $P$. azarasi. For the sequence KF806034 (ITS1, 5.8S, ITS2 and 28S), the results for $P$. decipiens were as follows: identity $=100 \%$, query cover $=98 \%$ and maximum score $=1607$, and for $P$. azarasi : identity $=100 \%$, query cover $=95 \%$ and maximum score $=1559$. While the cox-2 gene BLAST analysis resulted in a greater similarity to $P$. azarasi than to $P$. decipiens, the maximum score and query cover were greater for $P$. decipiens. For other genes, $P$. decipiens showed the higher values. The higher scores for $P$. decipiens can be explained by a longer query cover for $P$. decipiens than for $P$. azarasi, even though the similarity to $P$. azarasi was closer than to $P$. decipiens. Thus, the BLAST analysis pointed to the species $P$. decipiens. The finding of $P$. decipiens in salted $G$. morhua sold in Brazil is in accordance with a previous report (PEREIRA et al., 2000) and is now confirmed by a molecular approach. The alignment with Pseudoterranova species showed eight nucleotide differences between $P$. decipiens (this study) and $P$. azarasi (Figure 2).

Two different phylogenetic trees were generated (ML and BI) and provided similar results. Using the maximum likelihood tree (Figure 3), our sequence (KF806035) was closer to sequences of P. decipiens (accession numbers HM147278 and AF179920) than to the sequence of $P$. azarasi (accession number HM147281), despite the low bootstrap value (41\%). However, compared to $P$. azarasi, the clade composed of these three $P$. decipiens sequences showed a considerably higher bootstrap value (84\%). In the IB tree (Figure 4), the same group of sequences exhibited a reasonable posterior probability (58\%) and a higher bootstrap value (89\%). In accordance with Timi et al. (2014), our phylogenetic trees strongly
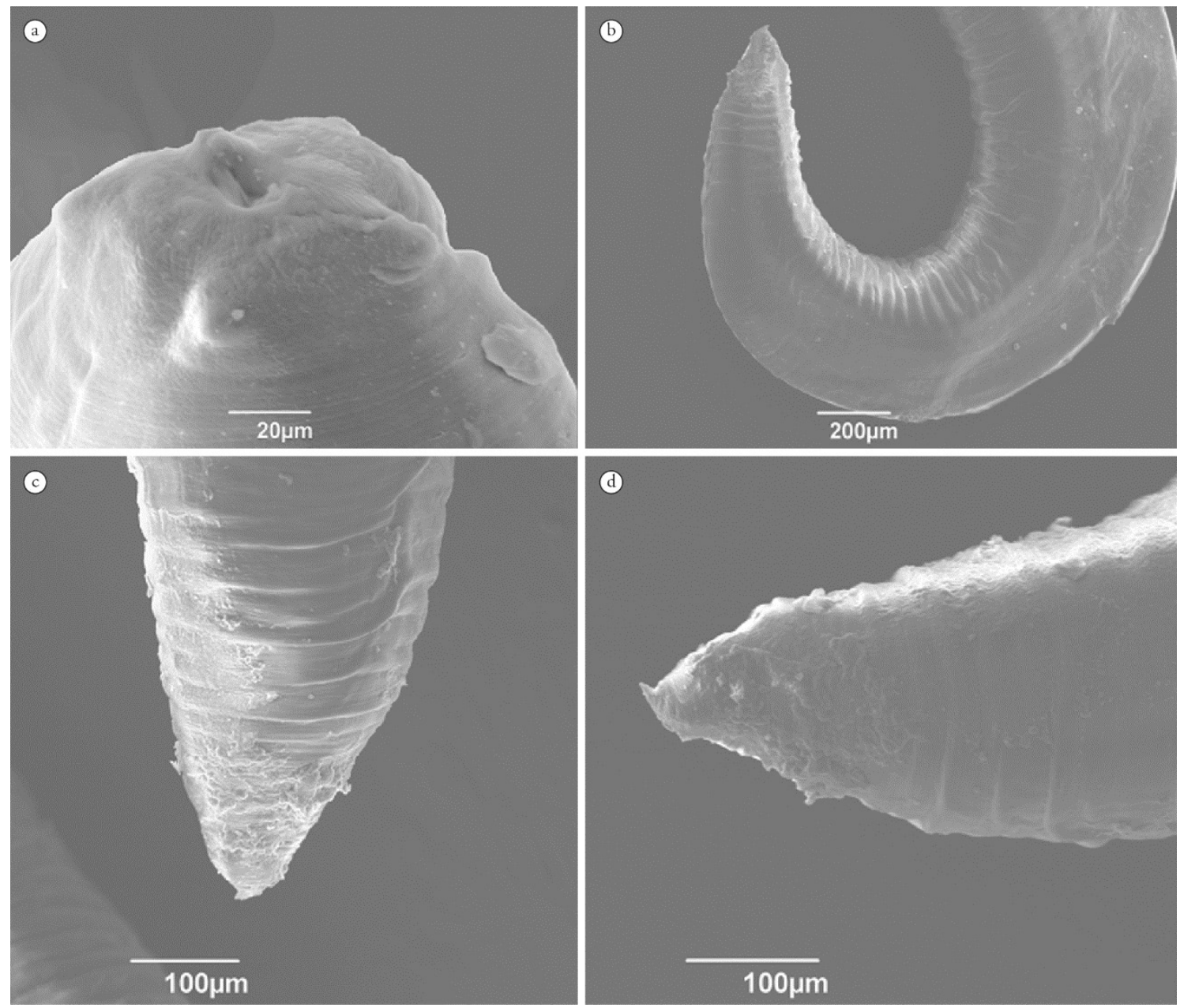

Figure 1. Scanning electron microscopy of L3 larva of Pseudoterranova decipiens (s.s.): a) anterior region with dorsal lip bearing two double papillae, a boring tooth situated between the two ventro-lateral lips and the oral aperture; b-d) tail with a mucron. 


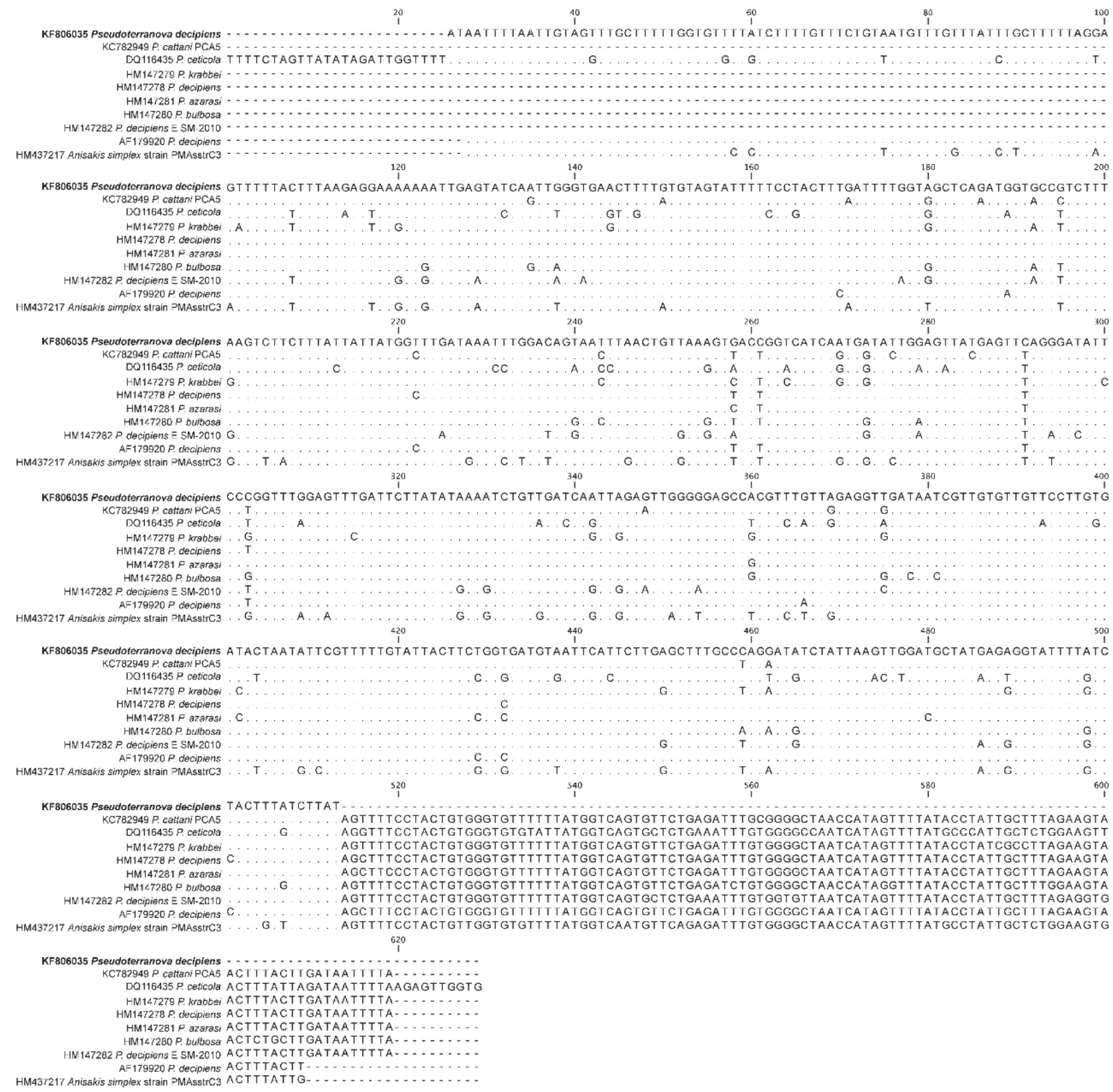

Figure 2. Sequence alignments of Pseudoterranova species. The numbers above the sequences represent nucleotide position. The dots indicate equal nucleotides compared with the sequence of $P$. decipiens found herein (in bold). A dash represents a gap.

support $P$. decipiens sp. E (accession number HM 147282-1) as a sister taxon to the remaining species of the $P$. decipiens complex.

Phylogenetic analyses are important, since the species $P$. decipiens and $P$. azarasi are very closely related (MATTIUCCI \& NASCETTI, 2008). The identification of $P$. decipiens in commercial food fish such as cod can have both economic and public health impacts, with wild fisheries sustaining considerable losses due to possible recommendations by international or regional regulatory agencies to forbid the consumption of salted and dried fish. As many as 107 parasite species, including both protozoan and metazoan forms, have been identified in G. morhua alone (HEMMINGSEN \& MACKENZIE, 2001). The finding of codworm $P$. decipiens (s. s.) in marketable cod in Brazil therefore rings an alarm bell in terms of a public health risk in this country.

As an emerging zoonosis first diagnosed in the Netherlands in 1955 (VAN THIEL et al., 1960; SAKANARI \& MCKERROW, 1989; ISHIKURA, 2003), anisakiasis, the disease caused by the ingestion and establishment of anisakid larvae in the human gastrointestinal tract, has received considerable attention in recent years. There are many reports of its occurrence in marketable cod and other dried, salted 


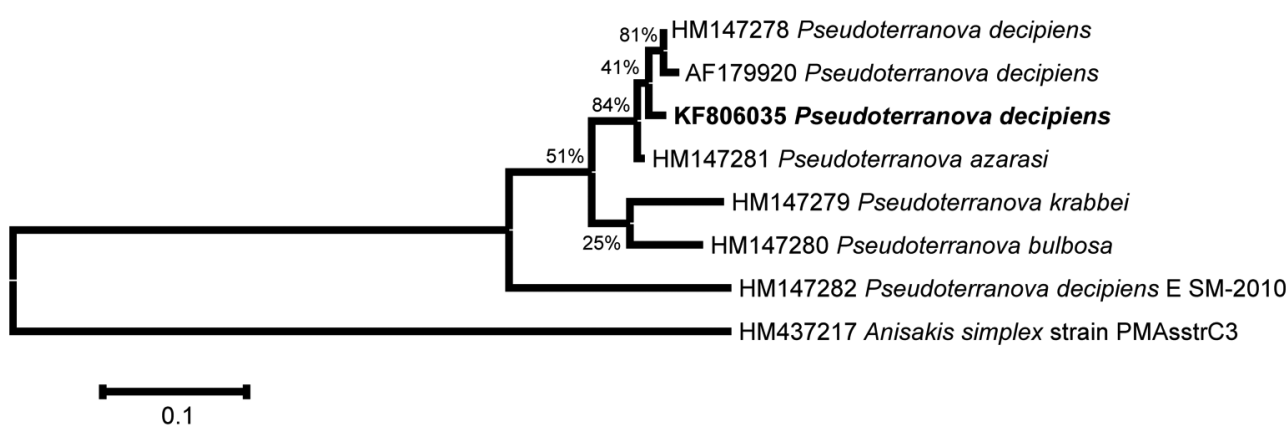

Figure 3. Phylogenetic tree based on the Maximum Likelihood of the partial cytochrome c oxidase subunit II gene, showing the relationship of Pseudoterranova decipiens (bold) with others species of Pseudoterranova. Numbers (percentage) on the branches indicate 5,000 bootstrap replicates. GenBank accession numbers are shown. Scale bars indicate the nucleotide mutations per site.

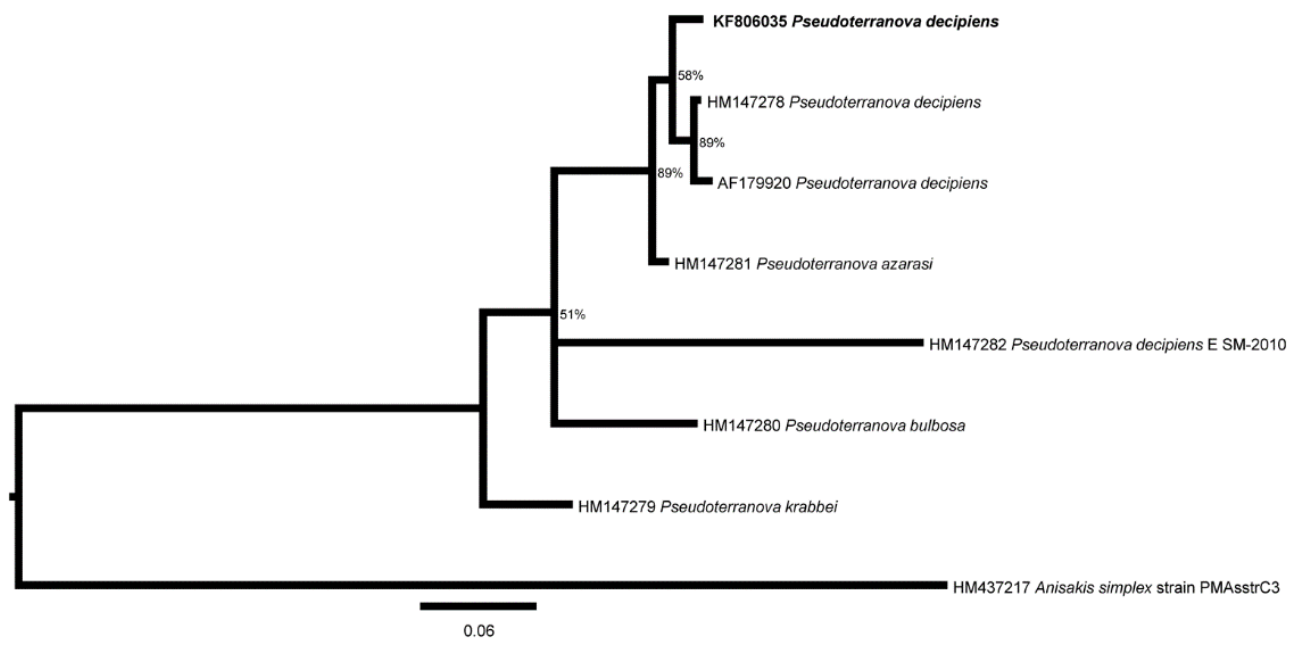

Figure 4. Phylogenetic tree based on the Bayesian inference of the partial cytochrome c oxidase subunit II gene, showing the relationship of Pseudoterranova decipiens (bold) with others species of Pseudoterranova. Numbers (percentage) on the branches indicate the posterior probability. After 2,000,000 generations a convergence was achieved. GenBank accession numbers are shown. Scale bars indicate the nucleotide mutations per site.

or fresh fish (e.g., TORRES et al., 2007; ARIZONO et al., 2011; MATTIUCCI et al., 2013; NIEUWENHUIZEN \& LOPATA, 2013). Anisakiasis, including pseudoterranoviasis, represents an emerging public health problem in Brazil that requires greater attention by physicians and by sanitary and epidemiological services, especially considering the possibility of allergic reactions resulting from the ingestion of these larvae. In a recent recommendation, consultants of Brazil's Ministry of Health included $P$. decipiens on the Classification List of Biological Risks as a potential hazard for humans (BRASIL, 2010). This is the first molecular and ultrastructural study of Pseudoterranova decipiens (sensu stricto) in imported cod sold in Brazil. This report on the identification and occurrence of this parasite in imported cod underscores the need for a rational government program for the risk management of anisakid nematode larvae.

\section{References}

Alonso A, Daschner A, Moreno-Ancillo A. Anaphylaxis with Anisakis simplex in the gastric mucosa. $N$ Engl J Med 1997; 337(5): 350-351. http://dx.doi.org/10.1056/NEJM199707313370518. PMid:9235506.
Altschul SF, Gish W, Miller W, Myers EW, Lipman DJ. Basic local alignment search tool. J Mol Biol 1990; 215(3): 403-410. http://dx.doi. org/10.1016/S0022-2836(05)80360-2. PMid:2231712.

Amato V No, Amato JG, Amato VS. Probable recognition of human anisakiasis in Brazil. Rev Inst Med Trop Sao Paulo 2007; 49(4): 261-262. PMid: 17823758 .

Arizono N, Miura T, Yamada M, Tegoshi T, Onishi K. Human infection with Pseudoterranova azarasi roundworm. Emerg Infect Dis 2011; 17(3): 555-556. http://dx.doi.org/10.3201/eid1703.101350. PMid:21392460.

Audicana MT, Kennedy MW. Anisakis simplex: from obscure infectious worm to inducer of immune hypersensitivity. Clin Microbiol Rev 2008; 21(2): 360-379. http://dx.doi.org/10.1128/CMR.00012-07. PMid:18400801.

Billings AN, Yu XJ, Teel PD, Walker DH. Detection of a spotted fever group rickettsia in Amblyomma cajennense (Acari: Ixodidae) in south Texas. J Med Entomol 1998; 35(4): 474-478. http://dx.doi.org/10.1093/ jmedent/35.4.474. PMid:9701930.

Borges JN, Cunha LFG, Santos HLC, Monteiro-Neto C, Portes Santos C. Morphological and molecular diagnosis of anisakid nematode larvae from cutlassfish (Trichiurus lepturus) off the coast of Rio de Janeiro, Brazil. PLoS One 2012; 7(7): e40447. http://dx.doi.org/10.1371/journal. pone.0040447. PMid:22792329. 
Brasil. Ministério da Saúde. Agência Nacional de Vigilância Sanitária Anvisa. Salted and dried salted fishes trading. Brasília; 2007. 30 p. [cited 2015 Jan 9]. Available from: http://www.anvisa.gov.br/alimentos/informes/ cartilha_bacalhau.pdf

Brasil. Classificação de risco dos agentes biológicos [online]. 2. ed. 2010. [cited 2014 Nov 10]. Available from: http://bvsms.saude.gov.br/bvs/ publicacoes/classificacao_risco_agentes_biologicos_2ed.pdf

Brasil. Fisheries and aquaculture statistical bulletin [online]. 2013 . [cited 2014 Out 22]. Available from: http://www.mpa.gov.br/images/Docs/ Informacoes_e_Estatisticas/Boletim\%20MPA\%202011FINAL.pdf

Buchmann K, Kania P. Emerging Pseudoterranova decipiens (Krabbe, 1878) problems in Baltic cod, Gadus morhua L., associated with grey seal colonization of spawning grounds. J Fish Dis 2012; 35(11): 861866. PMid:22817526.

Cabrera R, Luna-Pineda MA, Suárez-Ognio L. [New case of human infection by a Pseudoterranova decipiens larva (Nematode, Anisakidae) in Peru]. Rev Gastroenterol Peru 2003; 23(3): 217-220. PMid:14532923.

Catalano SR, Whittington ID, Donnellan SC, Gillanders BM. Parasites as biological tags to assess host population structure: Guidelines, recent genetic advances and comments on a holistic approach. Int J Parasitol Parasites Wildl 2014; 3(2): 220-226. http://dx.doi.org/10.1016/j. ijppaw.2013.11.001. PMid:25197624.

Chandra CV, Khan RA. Nematode infestation of fillets from Atlantic cod, Gadus morhua, off eastern Canada. J Parasitol 1988; 74(6): 1038-1040. http://dx.doi.org/10.2307/3282229. PMid:3193325.

Choi SC, Lee SY, Song HO, Ryu JS, Ahn MH. Parasitic infections based on 320 clinical samples submitted to Hanyang University, Korea (2004-2011). Korean J Parasitol 2014; 52(2): 215-220. http://dx.doi. org/10.3347/kjp.2014.52.2.215. PMid:24850969.

Cruz AR, Souto PCS, Ferrari CKB, Allegretti SM, Arrais-Silva WW. Endoscopic imaging of the first clinical case of anisakidosis in Brazil. Sci Parasitol 2010; 11(2): 97-100.

Del Rey Moreno A, Valero A, Mayorga C, Gómez B, Torres MJ, Hernández J, et al. Sensitization to Anisakis simplex s.l. in a healthy population. Acta Trop 2006; 97(3): 265-269. http://dx.doi.org/10.1016/j. actatropica.2005.11.007. PMid:16438926.

Felsenstein J. Evolutionary trees from DNA sequences: a maximum likelihood approach. J Mol Evol 1981; 17(6): 368-376. http://dx.doi. org/10.1007/BF01734359. PMid:7288891.

Fernández de Corres L, Audícana M, Del Pozo MD, Muñoz D, Fernández E, Navarro JA, et al. Anisakis simplex induces not only anisakiasis: report on 28 cases of allergy caused by this nematode. J Investig Allergol Clin Immunol 1996; 6(5): 315-319. PMid:8959543.

Floyd R, Abebe E, Papert A, Blaxter M. Molecular barcodes for soil nematode identification. Mol Ecol 2002; 11(4): 839-850. http://dx.doi. org/10.1046/j.1365-294X.2002.01485.x. PMid:11972769.

Fontenelle G, Knoff M, Felizardo NN, Lopes LM, Clemente SC. Nematodes of zoonotic importance in Cynoscion guatucupa (Pisces) in the state of Rio de Janeiro. Rev Bras Parasitol Vet 2013; 22(2): 281-284. http://dx.doi.org/10.1590/S1984-29612013005000019. PMid:23778824.

Hall TA. BioEdit: a user-friendly biological sequence alignment editor and analysis program for Windows 95/98/NT. Nucl Acids S 1999; 41: 95-98.

Hemmingsen W, MacKenzie K. The parasite fauna of the Atlantic cod, Gadus morhua L. Adv Mar Biol 2001; 40: 1-80.
Huelsenbeck JP, Ronquist F. MRBAYES: Bayesian inference of phylogenetic trees. Bioinformatics 2001; 17(8): 754-755. http://dx.doi.org/10.1093/ bioinformatics/17.8.754. PMid:11524383.

Ishikura H. Anisakiasis: clinical pathology and epidemiology. Progress of Medical Parasitology in Japan 2003; 8: 451-473.

Knoff M, São Clemente SC, Fonseca MCG, Felizardo NN, Lima FC, Pinto RM, et al. Anisakidae nematodes in the blackfin goosefish, Lophius gastrophysus Miranda-Ribeiro, 1915 purchased in the State of Rio de Janeiro, Brazil. Acta Sci Biol Sci 2013; 35(1): 129-133. http://dx.doi. org/10.4025/actascibiolsci.v35i1.12185.

Lima EJVMO, Sant'ana LS. Determinação de atividade de água, umidade e sal em peixes salgados e secos importados. Braz J Food Technol 2011; 14(2): 125-129. http://dx.doi.org/10.4260/BJFT2011140200016.

Luque JL, Aguiar JC, Vieira FM, Gibson DI, Santos CP. Checklist of Nematoda associated with the fishes of Brazil. Zootaxa 2011;3082: 1-88.

Margeirsson S, Jonsson GR, Arason S, Thorkelsson G. Influencing factors on yield, gaping, bruises and nematodes in cod (Gadus morhua) fillets. J Food Eng 2007; 80(2): 503-508. http://dx.doi.org/10.1016/j. jfoodeng.2006.05.032.

Mattiucci S, Fazii P, De Rosa A, Paoletti M, Megna AS, Glielmo A, et al. Anisakiasis and gastroallergic reactions associated with Anisakis pegreffi infection, Italy. Emerg Infect Dis 2013; 19(3): 496-499. http://dx.doi. org/10.3201/eid1903.121017. PMid:23621984

Mattiucci S, Nascetti G. Advances and trends in the molecular systematics of anisakid nematodes, with implications for their evolutionary ecology and host-parasite co-evolutionary processes. Adv Parasitol 2008; 66: 47-148. PMid:18486689.

Mattiucci S, Paggi L, Nascetti G, Portes Santos C, Costa G, Di Beneditto AP, et al. Genetic markers in the study of Anisakis typica (Diesing, 1860): larval identification and genetic relationships with other species of Anisakis Dujardin, 1845 (Nematoda: Anisakidae). Syst Parasitol 2002; 51(3): 159 170. http://dx.doi.org/10.1023/A:1014554900808. PMid:11912342.

McClelland G. The trouble with sealworms (Pseudoterranova decipiens species complex, Nematoda): a review. Parasitology 2002;124(07 Suppl Suppl): S183-S203. http://dx.doi.org/10.1017/S0031182002001658. PMid:12396224.

Mehrdana F, Bahlool QZM, Skovgaard A, Kuhn JA, Kania PW, Munk $P$, et al. Annual and spatial variability in endo- and ectoparasite infections of North Sea cod (Gadus morhua Linnaeus, 1758) larvae, post-larvae and juveniles. Acta Parasitol 2014; 59(2): 284-293. http://dx.doi.org/10.2478/ s11686-014-0244-0. PMid:24827100.

Mercado R, Torres P, Muñoz V, Apt W. Human infection by Pseudoterranova decipiens (Nematoda, Anisakidae) in Chile: report of seven cases. Mem Inst Oswaldo Cruz 2001; 96(5): 653-655. http://dx.doi.org/10.1590/ S0074-02762001000500010. PMid:11500763.

Na HK, Seo M, Chai JY, Lee EK, Jeon SM. A case of anisakidosis caused by Pseudoterranova decipiens larva. Korean J Parasitol 2013; 51(1): 115117. http://dx.doi.org/10.3347/kjp.2013.51.1.115. PMid:23467819.

Nadler SA, D’Amelio S, Dailey MD, Paggi L, Siu S, Sakanari JA. Molecular phylogenetics and diagnosis of Anisakis, Pseudoterranova, and Contracaecum from northern Pacific marine mammals. J Parasitol 2005; 91(6): 14131429. http://dx.doi.org/10.1645/GE-522R.1. PMid:16539026.

Nadler SA, Hudspeth DSS. Ribosomal DNA and phylogeny of the Ascaridoidea (Nemata: Secernentea): implications for morphological evolution and classification. Mol Phylogenet Evol 1998; 10(2): 221-236. http://dx.doi.org/10.1006/mpev.1998.0514. PMid:9878233. 
Nieuwenhuizen NE, Lopata AL. Anisakis--a food-borne parasite that triggers allergic host defences. Int J Parasitol 2013; 43(12-13): 10471057. http://dx.doi.org/10.1016/j.ijpara.2013.08.001. PMid:23994604.

Oliveira H, Pedro S, Nunes ML, Costa R, Vaz-Pires P. Processing of salted cod (Gadus spp.): A review. Comp Rev Food Sci Food Saf 2012; 11(6): 546-564. http://dx.doi.org/10.1111/j.1541-4337.2012.00202.x.

Perdiguero-Alonso D, Montero FE, Raga JA, Kostadinova A. Composition and structure of the parasite faunas of cod, Gadus morhua L. (Teleostei: Gadidae), in the North East Atlantic. Parasit Vectors 2008; 1(1): 23. http:// dx.doi.org/10.1186/1756-3305-1-23. PMid:18638387.

Pereira AD, Atui MB, Zamboni CQ, Torres DMAGV, Mangini ACS. Incidência de parasitos da família Anisakidae em bacalhau (Gadus morhua) comercializado no Estado de Sáo Paulo. Rev Inst Adolfo Lutz 2000; 59(1-2): 45-49.

Prado SPT, Capuano DM. [Report of nematodes of the Anisakidae family in codfish commercialized in Ribeirão Preto, SP]. Rev Soc Bras Med Trop 2006; 39(6): 580-581. http://dx.doi.org/10.1590/S003786822006000600016. PMid:17308709.

Pufall EL, Jones-Bitton A, McEwen SA, Brown TM, Edge VL, Rokicki J, et al. Prevalence of zoonotic anisakid nematodes in Inuit-harvested fish and mammals from the eastern Canadian Arctic. Foodborne Pathog Dis 2012; 9(11): 1002-1009. http://dx.doi.org/10.1089/fpd.2012.1186. PMid:22957974.

Qin Y, Zhao Y, Ren Y, Zheng L, Dai X, Li Y, et al. Anisakiasis in China: the first clinical case report. Foodborne Pathog Dis 2013; 10(5): 472-474. http://dx.doi.org/10.1089/fpd.2012.1325. PMid:23536984.

Ramanan P, Blumberg AK, Mathison B, Pritt BS. Parametrial anisakidosis. J Clin Microbiol 2013; 51(10): 3430-3434. http://dx.doi.org/10.1128/ JCM.01398-13. PMid:23863565.

Ramos P. Anisakis spp. In cod, sushi and sashimi: risk of parasitic infection and allergy. RPCV 2011; 110(577-580): 87-97.

Rodríguez MV, Tena EV, Calvillo MC, Villacampa MM. Recurrent abdominal pain: gastric and ileal infection by Anisakis. Med Interna 2006; 23(11): 556-557.

Sakanari JA, McKerrow JH. Anisakiasis. Clin Microbiol Rev 1989; 2(3): 278-284. PMid:2670191.
Suzuki J, Murata R, Hosaka M, Araki J. Risk factors for human Anisakis infection and association between the geographic origins of Scomber japonicus and anisakid nematodes. Int J Food Microbiol 2010; 137(1): 88-93. http://dx.doi.org/10.1016/j.ijfoodmicro.2009.10.001. PMid:19892425.

Tamura K, Peterson D, Peterson N, Stecher G, Nei M, Kumar S. MEGA5: molecular evolutionary genetics analysis using maximum likelihood, evolutionary distance, and maximum parsimony methods. Mol Biol Evol 2011; 28(10): 2731-2739. http://dx.doi.org/10.1093/molbev/msr121. PMid:21546353.

Thompson JD, Higgins DG, Gibson TJ. CLUSTAL W: improving the sensitivity of progressive multiple sequence alignment through sequence weighting, position-specific gap penalties and weight matrix choice. Nucleic Acids Res 1994; 22(22): 4673-4680. http://dx.doi.org/10.1093/ nar/22.22.4673. PMid:7984417.

Timi JT, Paoletti M, Cimmaruta R, Lanfranchi AL, Alarcos AJ, Garbin $\mathrm{L}$, et al. Molecular identification, morphological characterization and new insights into the ecology of larval Pseudoterranova cattani in fishes from the Argentine coast with its differentiation from the Antarctic species, P. decipiens sp. E (Nematoda: Anisakidae). Vet Parasitol 2014; 199(1-2): 59-72. http://dx.doi.org/10.1016/j.vetpar.2013.09.033. PMid:24161261.

Torres P, Jercic MI, Weitz JC, Dobrew EK, Mercado RA. Human pseudoterranovosis, an emerging infection in Chile. J Parasitol 2007; 93(2): 440-443. http://dx.doi.org/10.1645/GE-946R.1. PMid:17539437.

Umehara A, Kawakami Y, Matsui T, Araki J, Uchida A. Molecular identification of Anisakis simplex sensu stricto and Anisakis pegreffii (Nematoda: Anisakidae) from fish and cetacean in Japanese waters. Parasitol Int 2006; 55(4): 267-271. http://dx.doi.org/10.1016/j. parint.2006.07.001. PMid:16942906.

Van Thiel P, Kuipers FC, Roskam RTH. A nematode parasitic to herring, causing acute abdominal syndromes in man. Trop Geogr Med 1960; 12: 97-113. PMid:13776308.

Vidacek S, Heras C, Solas MT, Mendizábal A, Rodriguez-Mahillo AI, González-Muñoz M, et al. Anisakis simplex allergens remain active after conventional or microwave heating and pepsin treatments of chilled and frozen L3 larvae. J Sci Food Agric 2009; 89(12): 1997-2002. http:// dx.doi.org/10.1002/jsfa.3677.

Yu JR, Seo M, Kim YW, Oh MH, Sohn WM. A human case of gastric infection by Pseudoterranova decipiens larva. Korean J Parasitol 2001; 39(2): 193-196. http://dx.doi.org/10.3347/kjp.2001.39.2.193. PMid:11441507. 